Pesq. Vet. Bras. 36(Supl.1):71-78, junho 2016 DOI: $10.1590 / \mathrm{S} 0100-736 \mathrm{X} 2016001300011$

\title{
Culture, characterization and differentiation of neural precursors from the central nervous system of guinea pigs (Cavia porcellus Linnaeus, 1758) ${ }^{1}$
}

\author{
Erika Toledo da Fonseca, ${ }^{2,4 *}$, Layla Testa Galindo ${ }^{3}$, Marimélia A. Porcionatto ${ }^{3}$ \\ and Maria Angélica Miglino ${ }^{4}$
}

\begin{abstract}
Fonseca E.T., Galindo L.T., Porcionatto M.A. \& Miglino M.A. 2016. Culture, characterization and differentiation of neural precursors from the central nervous system of guinea pigs (Cavia porcellus Linnaeus, 1758). Pesquisa Veterinária Brasileira 36(Supl.1):7178. Escola de Medicina Veterinária e Zootecnia, Universidade Federal do Tocantins, BR-153 Km 112, Rural, Araguaína, Tocantins, TO 77804-970, Brazil. E-mail: erikafonseca@uft.edu.br

Potentially neurogenic areas were initially identified by incorporation of bromodeoxyuridine (BrdU) in cells underlying the subventricular zone (SVZ) of the lateral ventricles wall, hippocampus and olfactory bulbs of newborn guinea pigs. Neural precursors from the SVZ were cultured in suspension, generating neurospheres (NSFs), which, upon dissociation were able to generate new NSFs. Upon culture in the absence of growth factors, cells dissociated from NSFs displayed evidence for neural differentiation, giving rise to cells from neural lineage. Flow cytometry analysis for of NSFs-derived cells after differentiation revealed approximately $13.3 \%$ nestin positive, $5.5 \%$ Beta-III-tubulin positive, $9 \%$ GFAP positive and $7.8 \% \mathrm{mGalC}$ positive. Functional assays by measurement of calcium influx upon gamma butiric amino acid (GABA) and glutamate stimuli, revealed stimulation in differentiated cells, an indicator of neuronal differentiation. The ability of guinea pig SVZ cells to originate functional neurons in vitro is promising for research and towards a future use of neural stem cells in the therapy of neurological disorders.
\end{abstract}

INDEX TERMS: Guinea pigs, neural stem cells, subventricular zone, culture, in vitro characterization.

RESUMO.- [Cultura, caracterização e diferenciação de precursores neurais do sistema nervoso central de porquinho-da-índia (Cavia porcellus Linnaeus, 1758).] Áreas potencialmente neurogênicas foram identificadas por incorporação de bromodeoxiuridina (BrdU) na zona subventricular (SVZ) dos ventrículos laterais, hipocampo e bulbos olfatórios de cobaias neonatos. Precursores neurais provenientes da SVZ foram cultivados em suspensão, resultando na geração de neuroesferas (NSFs), que quando dissociadas foram capazes de proliferar e gerar novas NSFs. Quando cultivadas na ausência de fatores de crescimento, as

\footnotetext{
${ }^{1}$ Received on June 16, 2015.

Accepted for publication on April 1, 2016.

${ }^{2}$ Escola de Medicina Veterinária e Zootecnia, Universidade Federal do Tocantins (UFT), BR-153 Km 112, Rural, Araguaína, Tocantins, TO 77804970, Brazil. *Corresponding author: erikafonseca@uft.edu.br

${ }^{3}$ Departamento de Bioquímica, Universidade Federal de São Paulo (Unifesp), Rua Pedro de Toledo 669, São Paulo, SP 04039-030. Brazil.

${ }^{4}$ Departamento de Cirurgia, Faculdade de Medicina Veterinária e Zootecnia, Universidade de São Paulo (USP), Av. Prof. Orlando Marques de Paiva 87, São Paulo, SP 05508-270, Brazil.
}

células provenientes de NSFs dissociadas apresentaram evidências de diferenciação neuronal, dando origem a células da linhagem neural. Citometria de fluxo em células das NSFs após a diferenciação revelou aproximadamente 13,3\% positivas para nestina, $5,5 \%$ positivas para Beta-III-tubulina, $9 \%$ positivas para GFAP e $7,8 \%$ positivas para mGalC. Testes de funcionalidade pela mensuração de influxo de cálcio após estímulo com ácido gama amino butírico (GABA) e glutamato revelaram a estimulação de células diferenciadas, um indicador de função neuronal. A capacidade de células da SVZ de fetos de cobaias originarem células neurais funcionais in vitro é promissora para a pesquisa e eventual uso terapêutico de células tronco em disordens do sistema nervoso.

TERMOS DE INDEXAÇÃO: Cobaios, células-tronco neurais, zona subventricular, cultura, caracterização in vitro.

\section{INTRODUCTION}

Neural stem cells (NSCs) are defined by two functional properties: (1) self renewal, the capacity to generate identical progeny and (2) multipotentiality, the capacity to generate 
the main neural cells, e.g. neurons, astrocytes and oligodendrocytes (Conti et al. 2006). The potential applications of NSCs in degenerative and traumatic diseases therapy in the central nervous system (CNS) have called tremendous scientific interest.

During vertebrate embryonic development, CNS cells may be originated from virtually all regions of the neuroepithelium. Two well characterized neurogenic regions are the dentate gyrus (DG) of the hippocampus (Altman \& Das 1967, Lacbawan \& Muenke 2002) and the subventricular zone (SVZ) of the lateral ventricles (Götz \& Huttner 2005). The SVZ is a thin layer in the wall of the lateral ventricles that contains neural progenitor cells able to generate neurons and glial cells (Alvarez-Buylla \& Lois 1995).

García-Verdugo et al. (1998) highlighted the main immunostaining properties of the cell types found in the CNS: nestin antibodies react with embryonic neuroepithelial cells and, thus, nestin has been suggested as the marker for NSCs. In the adult SVZ, nestin is expressed in multiple cell types, including ependymal cells. Vimentin and GFAP glial markers are present in astrocytes, yet apparently not in neurons. PSA-NCAM antibodies and neuron-specific Beta-III-tubulin antibodies (Tuj1 for example) stain only neurons. The pattern of recognition by cellular marker-specific antibodies suggests that precursor cells are the most immature since they express only nestin and do not express other markers of differentiation. The most used markers for neural precursors and differentiated cells include include Nestin, Sox2 (Schwartz et al. 2003), GFAP, Beta-III-tubulin (Buddensiek et al. 2010, Piper et al. 2001, Schwartz et al. 2003), MAP2ab (Buddensiek et al. 2010; Schwartz et al. 2003), Vimentin, NeuN, (Schwartz et al. 2003), mGalC (Piper et al. 2001, Buddensiek et al. 2010) and 04 (Piper et al. 2001, Schwartz et al. 2003).

Neural regeneration should be considered in three main applications: (1) regeneration of interrupted/disrupted neuronal axons; (2) replacement of damaged neural cells and (3) rescue of neural functions (Okano 2010). The observation that all cells of the CNS are derived from NSCs originated in different regions of the brain has stimulated the scientific community for mapping and characterizing neurogenic areas and investigating the aplicability of NSCs in the therapy of neurological disorders as multiple sclerosis (Manganas and Maletic-Savatic, 2005), Parkinson's disease, stroke, spinal trauma (Jandial et al., 2007) and many lesions/diseases of the nervous system (Mansergh et al. 2004).

Although adult neurogenesis is an event that occurs in several animal species, the rate of production of neural cells exhibits notable differences among species. Interestingly, the pattern of development of the DG in guinea pigs is more similar to that of humans than other species (Guidi et al. 2005). In addition, guinea pigs display an extensive pre-birth development of the brain leading to a full formation of the volumous cerebral hemispheres (Potter \& Brueck 1958).

Therefore, this study aimed to culture, to characterize and to differentiate neural precursors obtained from the SVZ of guinea pigs fetuses.

\section{MATERIALS AND METHODS}

Twenty one fetuses and two neonates from nine pregnant guinea pig females from a particular breeder were used. All experimental procedures were performed under veterinary supervision, according to recommendations by the National Council for Control of Animal Experimentation from Brazil, under license number 1999/2010 from the University of São Paulo Ethics Committee on Animal Experimentation.

Female guinea pigs near the end of pregnancy were sedated by intramuscular administration of azaperone $(4 \mathrm{mg} / \mathrm{kg})$ followed by administration of cloridrate of ketamine $(20 \mathrm{mg} / \mathrm{kg})$ and xilazine $(1.5 \mathrm{mg} / \mathrm{kg})$. Fetuses were aseptically removed upon laparotomy.

BrdU staining. For BrdU staining, two one-day-old guinea pigs received intraperitonial administrations of 5-bromo-2'deoxyuridine (BrdU; $50 \mathrm{mg} / \mathrm{kg}$ ) every $12 \mathrm{~h}$ during 2 days. Twelve hours after the last administration they were sedated by intramuscular administration of cloridrate of ketamine $(20 \mathrm{mg} / \mathrm{kg}$ ) and xilazine $(1.5 \mathrm{mg} / \mathrm{kg}$ ) and perfused with $4 \%$ parafolmaldeyde (PFA). Brain was removed from the skull, sectioned along the midline and remains PFA in PBS for $4 \mathrm{~h}$ at $4^{\circ} \mathrm{C}$. After washing, the tissue was dehydrated in $30 \%$ sacarose at $4^{\circ} \mathrm{C}$ overnight, followed by inclusion in Tissue Tek - OCT (FK Biotec) and frozen. $20 \mu \mathrm{m}$ sections were cut in a criostat, layed on glass slides and stored at $-20^{\circ} \mathrm{C}$. Slides were incubated with $0.1 \%$ Triton X-100 in PBS at RT for 10 min followed by washing with $0.1 \mathrm{M}$ TBS pH 7.4. Blocking was performed with 5\% FBS and $0.1 \%$ Triton X-100 for $1 \mathrm{~h}$ at RT. Then slides were incubated with an anti-BrdU antibody (rat, Abcam, 1:100) in $0.1 \%$ triton X-100 in TRIS-borate buffer for 30 min. After washings in PBS and $\mathrm{H}_{2} \mathrm{O}$, sections were incubated with a secondary antibody (anti-rat IgG, Alexa ${ }^{488}$ conjugated, Abcam) for additional $30 \mathrm{~min}$. For nuclei visualization, slides were stained with DAPI (4'-6-diamidino-2-fenilindol, Molecular Probes) for 10 min. Then, slides were washed, mounted and examined in a confocal scope (Zeiss ${ }^{\circledR}$ model LSM510).

Cell cultures. Fetal brains were removed and placed on Petri dishes containing high glucose DMEM (4.5g/l) (Dulbecco's Modified Eagle Medium, Sigma). Fragments obtained from the SVZ were transferred to tubes containing $1 \mathrm{ml}$ of high glucose DMEM (Sigma). After tissue sedimentation, the DMEMwas removed and tissue fragments were incubated with $1 \mathrm{ml}$ TrypL $E^{\mathrm{tm}}$ (GibcoBRL; $0.1 \%)$, EDTA $(10 \mathrm{mM})$, pH 6.3 for $5 \mathrm{~min}$ at $37^{\circ} \mathrm{C}$. TrypL $E^{\mathrm{tm}}$ was inactivated with fetal bovine serum (FBS, Cultilab) and the material was homogeneized and centrifuged at $400 \mathrm{xg}$ for $5 \mathrm{~min}$. Supernatant was removed and the pellet ressuspended in culture medium as described below. Tissues were dissociated by multiple passages under high pressure through pipete tips of $1000 \mu \mathrm{l}$ to $200 \mu \mathrm{l}$ until a cell suspension was obtained. The cell suspension was filtered through a $40 \mu \mathrm{m}$ filter (BD) and placed on $75 \mathrm{~cm}^{2}$ culture dishes previously treated with Poly-Hema (Poli [2-hidroxyetil metacrilate], Sigma). Culture medium consisted of high glucose DMEM (Sigma; 70\%), HAM'S F12 (LGC Biotecnologia; 30\%), penicilin/ streptomycin (Gibco BRL; 1\%), supplement B27 (Gibco BRL; 2\%), EGF (Sigma; 20ng/ml), FGF (R\&D, 20ng/ml), heparin (Sigma; 5g/ $\mathrm{ml}$ ), L-Glutamine (Sigma; $2 \mathrm{mM}$ ). $50 \%$ of Culture medium was replaced every 4 to 5 days until the formation of the NSFs. NSFs Dissociation in individual cells was achieved by Tryp $L E^{\mathrm{tm}}$ incubation for $5 \mathrm{~min}$ at $37^{\circ} \mathrm{C}$, followed by gentle pipeting the cell suspension until complete dissociation.

Differentiation. NSFs were harvested and transferred to laminin and poly-L-lisine coated sterile coverslips to allow cell adhesion in 24-well plates. The culture medium consisted of high glucose DMEM (Sigma; 70\%), HAM'S F12 (LGC Biotecnologia; $30 \%$ ), penicillin/streptomycin (GibcoBRL; 1\%), suplement B27 (Gibco BRL; 2\%). After 7 days, culture medium was removed and 
cells were fixed in 4\% PFA for 20 min at room temperature (RT). Then PFA was removed, cells were washed three times with $0.1 \mathrm{M}$ TBS and immunofluorescence and cytometry analysis were performed.

Immunofluorescence for neuronal markers. NSCs as NSFs or single cells were cultured in 24-well plates covered by laminin and poli-L-lisine-treated coverslips at $37^{\circ} \mathrm{C}$ for 7 days. Then, cells were fixed in 4\% PFA for $20 \mathrm{~min}$ at RT, washed three times with $0.1 \mathrm{M}$ TBS and incubated with $0.1 \%$ Triton X-100 in PBS at RT for $10 \mathrm{~min}$ followed by washing with $0.1 \mathrm{M}$ TBS $\mathrm{pH}$ 7.4. Blocking was performed with 5\% FBS and $0.1 \%$ Triton X-100 for $1 \mathrm{~h}$ at RT. Slides were incubated with each of the following primary antibodies overnight at $4^{\circ} \mathrm{C}$ : anti-Nestin (rabbit, Sigma, 1:10), anti-GFAP (rabbit, Abcam, 1:50), anti-galactocerebroside (mGalC) (mouse, Millipore, $5 \mu \mathrm{g}$ ) and anti- $\beta$-III Tubulin (mouse, Abcam, 1:50). Slides were washed twice with $0.1 \mathrm{M}$ TBS and incubated with the secondary antibodies for an additional hour at $37^{\circ} \mathrm{C}$ : anti-rabbit IgG TEXAS RED conjugated (Santa Cruz Biotechnology, 1:300), anti-rabbit IgG FITC-conjugated (Sigma, 1:200), anti-mouse IgG FITC-conjugated (Santa Cruz Biotechonoly, 1:200). Slides were then washed twice in 0.1 M TBS, mounted with Vectashield (Vector Laboratories) and examined in an Eclipse E600 ultraviolet microscope (Nikon).

Flow cytometry. NSFs were cultured in Petri dishes treated with poly-L-lisin and laminin as described above in the same culture medium used for cell differentiation and cells were cultured for 10 days. After this period, culture medium was removed, cells were dissociated as described above the supernatant discarded. cell pellet was washed with PBS and permeabilized with $0.1 \%$ Triton X-100 in PBS for 6 min at RT, followed by PBS washing and incubationfor $1 \mathrm{~h}$ at RT with the following primary antibodies, individually: polyclonal anti-Nestin (rabbit, Sigma, 1:10), polyclonal anti-GFAP (rabbit, Abcam, 1:50), monoclonal anti-galactocerebroside (mGalC) (mouse, Millipore, $5 \mu \mathrm{g}$ ) and monoclonal anti- $\beta$-III Tubulin (mouse, Abcam, 1:50). Then the cells were washed with PBS and incubated for an additional hour with the respective secondary antibodies: anti-rabbit IgG TEXAS RED conjugated (Santa Cruz Biotechnology, 1:300), anti-rabbit IgG FITC-conjugated (Sigma, 1:200), anti-mouse IgG FITC-conjugated (Santa Cruz Biotechonoly, 1:200). Cells were then fixed in 1\% PFA in PBS containing 1\% BSA for 15 min at RT, followed by PBS washing and ressuspension in $1 \mathrm{~mL}$ PBS. Analysis were performed in a flow cytometer (Attune ${ }^{\circledR}$ Acoustic Focusing Cytometer, Applied Biosystem) using the Attune Cytometric Software V1.2.5, with acquisition of, at least 5.000 events. The flow cytometer was calibrated with the following controls: cell suspension without antibody; cell suspension incubated with Alexa ${ }^{488}$ secondary antibody only and cell suspension incubated with Alexa ${ }^{647}$ secondary antibody only. Parameters were adjusted to remove any contribution by unlabelled cells.

Modulation of intracellular $\mathrm{Ca}^{2+}$. Intracellular $\mathrm{Ca}^{2+}$ influx assay was performed to investigate the functionality of NSCs submitted to differentiation. NSFs were cultured for 10 days over poly-l-lysin and laminin-coated coverslips in 24-well plates in the same medium used for differentiation. Culture medium was replaced every three days. Then, culture medium was removed and cells incubated with buffer A $(116 \mathrm{mM} \mathrm{NaCl}, 5.4 \mathrm{mM} \mathrm{KCl}, 0.8 \mathrm{mM}$ MgSO4, 5.5mM D-Glucose, 50mM MOPS, $1 \mathrm{mM} \mathrm{CaCl}_{2}$, pH 7.2) supplemented with $5 \mu$ M Fluo-3 AM (Molecular Probes, Caslsbad, CA) at RT for $30 \mathrm{~min}$. Cells were washed twice with buffer A. The neurotransmitters gama-aminobutiric acid (GABA) (Sigma, 5nM) and glutamate (Sigma, $5 \mathrm{mM}$ ) were added, separatedly, to the medium. The drug Thapsigargin (THG) (Sigma, $2 \mathrm{nM}$ ) was used as positive control. After addition of each neurotransmitter or THG, fluorescence was observed and images were captured in a fluorescence Carl Zeiss AxioObserver Z1 microscope.

\section{RESULTS}

\section{Identification of neurogenic areas}

BrdU was administered in two guinea pig neonates in order to identify brain areas with cell proliferation and, thus, with neurogenic potential. BrdU positive cells were observed in the SVZ (Fig.1A), hippocampus (Fig.1B) and olfactory bulbs (Fig.1C). No staining was observed in other areas of the brain, indicating that the staining was specific for areas presenting cellular proliferation. As BrdU incorporation indicates cellular proliferation, these data suggest that these areas may be potentially neurogenic in neonate guinea pigs.

\section{SVZ culture and NSFs formation}

Upon culture in appropriate medium, cells derived from the SVZ of guinea pig fetuses near to term were cultured in suspension and were able to generate NSFs. The primary NSFs were typically observed after 7 to 10 days in culture. NSFs are multicellular aggregates, varying in size, rounded that fluctuate in the culture medium (Fig. 2A). The number of cells and, consequently, the size of NSFs increased
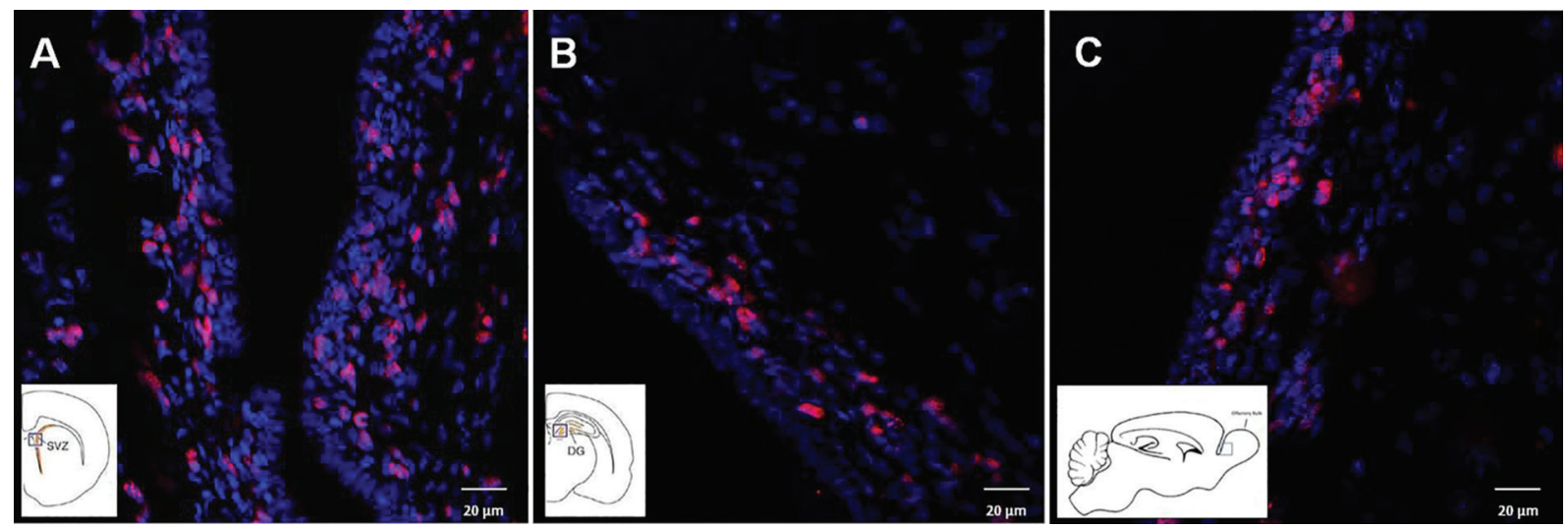

Fig.1. Incorporation of BrdU in neurogenic areas of the brain of neonate guinea pigs. One-day-old guinea pigs received BrdU administrations every $12 \mathrm{~h}$ during 2 days and were euthanized $12 \mathrm{~h}$ after the last injection. Brain sections were submitted to BrdU immunolabeling followed by DAPI staining. BrdU positive cells were found in SVZ in the lateral ventricle wall (A), hippocampus DG (B) and olfactory bulb (C). The insets show the localization of the respective sections in the brain. Bar=20 $\mu \mathrm{m}$. 


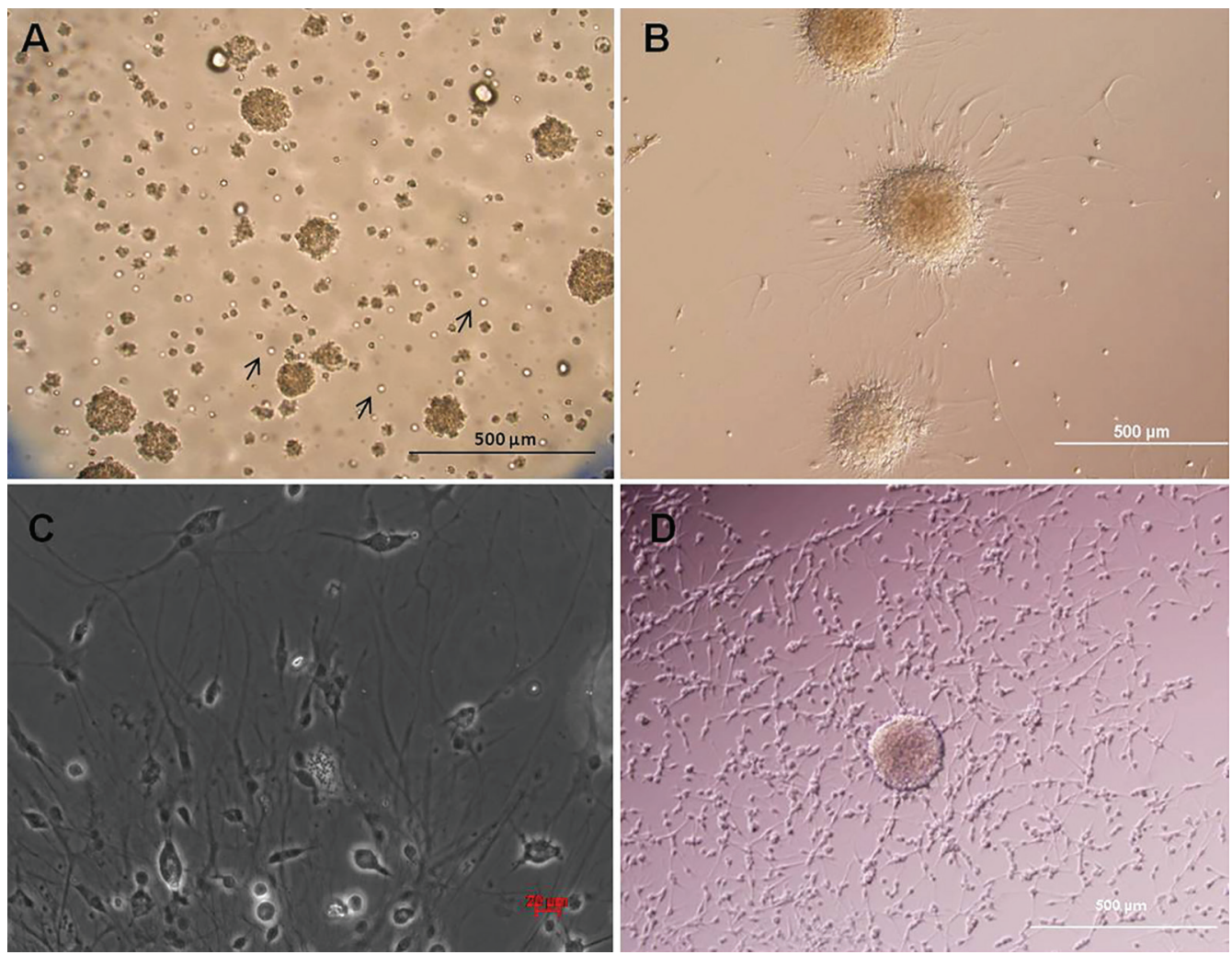

Fig.2. (A) Neurospheres derived from guinea pig fetuses SVZ. After nine days in culture NSFs can be visualized with variable diameters and there is still the presence of individual cells (arrows). Bar=500 $\mu \mathrm{m}$; (B) and (C) Differentiation assays of cells derived from the guinea pig SVZ cultured as NSFs. (B) Two days of differentiation. Note the presence of adherent and morphologically different cells in the periphery of NSFs. Magnification 10x. (C) Seven days of differentiation. Many cells morphologically different and adherent to the flask are observed. Magnification 20x. (D) Control cultures. The original NSF morphology is maintained. Magnification 10x.

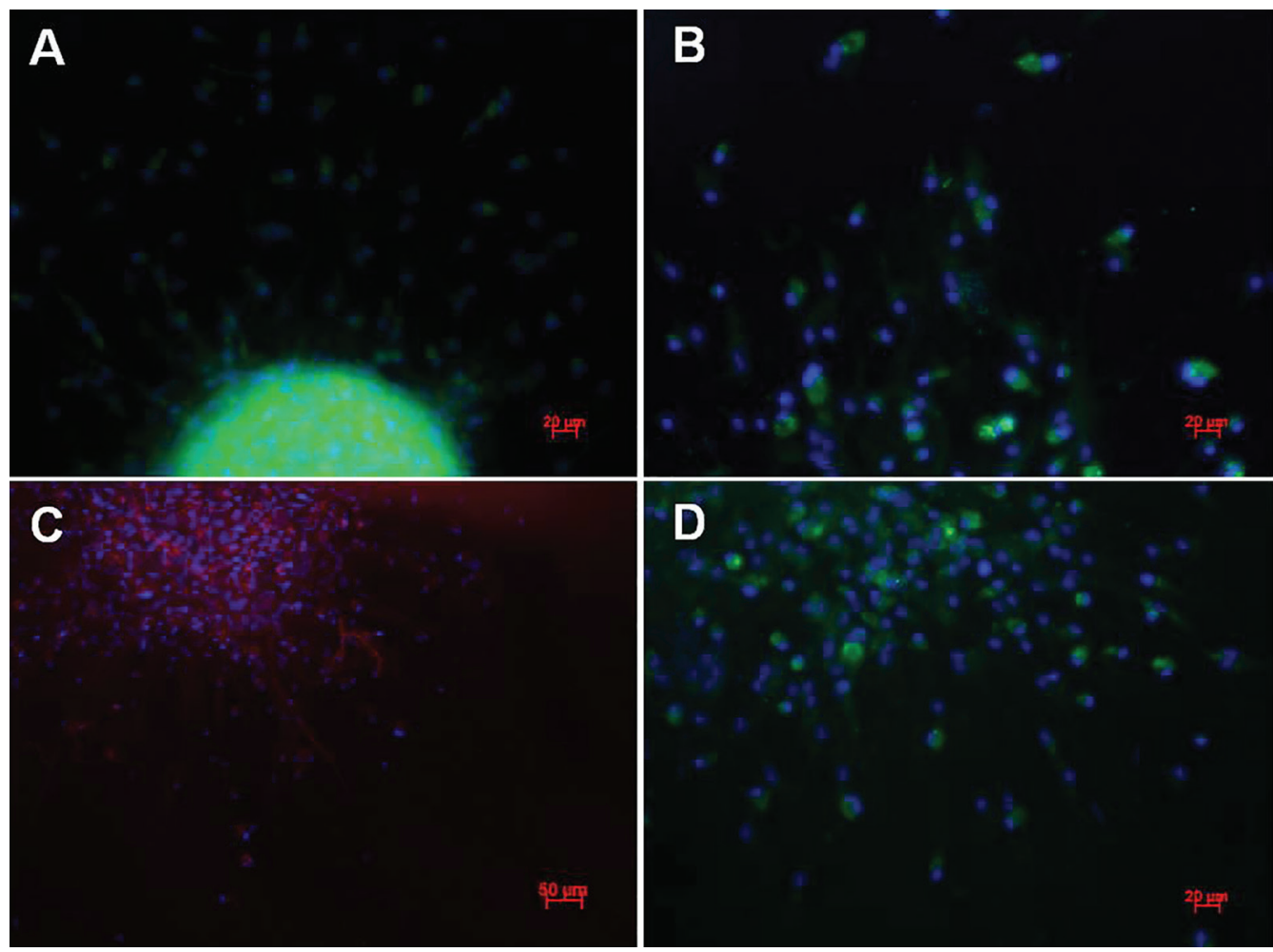

Fig.3. NSFs cells cultivated under differentiation conditions. (A) After differentiation, some cells kept the undifferentiated state and were positive for nestin. (B) Some cells were positive for Beta-III-tubulin, (C) GFAP and (D) mGalC, indicating neuron, astrocyte and oligo-

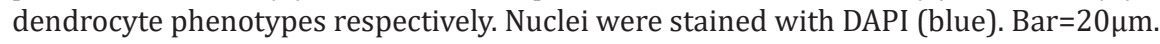


with time in culture. In addition to NSFs, numerous individualized cells, with irregular surface, refringent and non-adherent were also observed. After subculture, either with or without dissociation, NSFs-derived cells proliferated originating new and abundant NSFs. Typically, some NSFs cultures were subcultured up to 6 to 7 times, every approximately 7 days, reaching up to 60-70 days in culture. NSFs were successfully frozen and thawed, and they kept their proliferation ability (data not shown). Thus, these results demonstrate the proliferation ability of the cells derived from guinea pig SVZ and also show the potential of these cells to generate NSFs in vitro - a characteristic of neural precursors (Reynold \& Weiss 1992).

\section{Differentiation and neural markers}

For differentiation assays, NSFs were cultured in growth factors free media over poly-l-lysin and laminin-coated coverslips. Two days after differentiation stimuli, NSFs adhered to the surface and some cells started to migrate out the NSFs. A number of these cells sneaking off of the NSFs showed changed morphology (Fig.2B). After 7 days in culture, the identification of NSFs was no longer possible (Fig.2C). In contrast, NSFs grown in medium containing growth factors maintained their morphology and proliferation potential and did not display signs of differentiation (Fig.2D).

NSFs-derived cells induced to differentiation were positive for nestin (Fig.3A), Beta-III-tubulin (Fig.3B), GFAP (Fig.3C) and mGalC (Fig.3D). Nestin staining was observed in cells composing the NSFs and individualized cells as well. Many GFAP-positive cells were identified within NSFs. mGalC and Beta-III-tubulin-positive cells were better observed among cells detached from the NSFs than in cells inside the NSFs. These results show that NSFs induced to differentiate are composed by a mixed population of cells displaying markers of the main differentiated cells of the nervous system and markers of neural stem cells as well.

\section{Flow cytometry}

In order to quantify the cell populations generated after differentiation, NSFs were submitted to differentiation and after 10 days of culture, individualized NSF-derived cells were submitted to immunophenotypic identification by flow cytometry. Approximately $13.3 \%$ of cells were positive for neural stem cell marker nestin (Fig. 4A), 9\% were positive for the astrocyte marker GFAP (Fig. 4B), 7.8\% were positive for the oligodendrocyte marker mGalC (Fig. 4C) and $5.5 \%$ were positive for the neuronal marker beta-III-tubulin (Fig. 4D). Thus, culture of NSFs in differentiation medium results in cell populations displaying the main markers of differentiated neural cells, indicating the pluripotentiality of neural precursors present in NSFs.

\section{Modulation of intracellular $\mathrm{Ca}^{2+}$}

Calcium influx was used as an indicator of functionality of differentiated neural cells. After differentiation, neurotransmitters GABA and glutamate were added to the medium, separately, and images were collected continuously thereafter. THG, a plant-derived sesquiterpene lactone, was used as positive control since it discharges intracellular stored $\mathrm{Ca}^{2+}$. Static images taken at different time points after neurotransmitter addition are shown in Fig. 5. No activity was detected in control cells, without addition of any drug (Fig.5A and 5D), contrasting with staining of a high number of cells upon addition of THG (Fig.5C and 5F). Stimulation of a variable number of cells was observed after addition of the excitatory neurotransmitter glutamate (Fig.5B) and the inhibitory neurotransmitter GABA (Fig.5E). These findings indicate that NSF-derived neural cells induced to differentiate display physiologic indicators of neuron functionality.

\section{DISCUSSION}

The results obtained in the experiments described herein demonstrate the presence of NSCs in the SVZ of guinea pig fetuses near birth. Upon dissociation and culture under
A
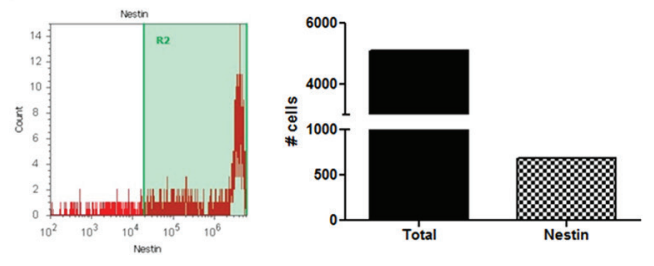

C
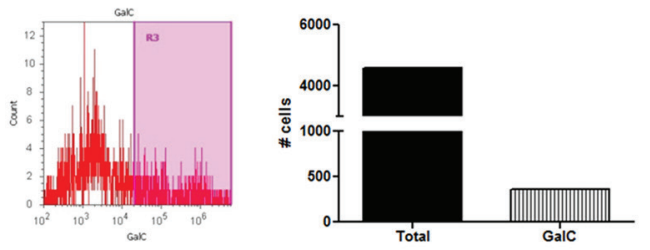

B
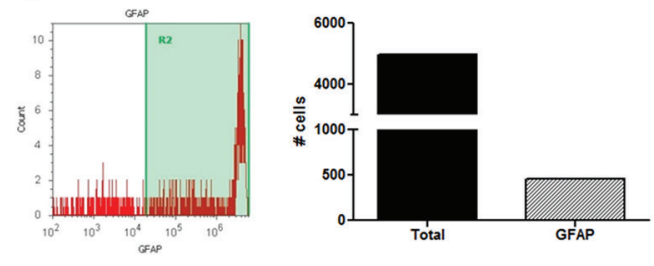

D

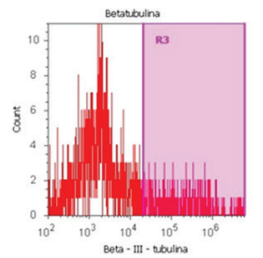

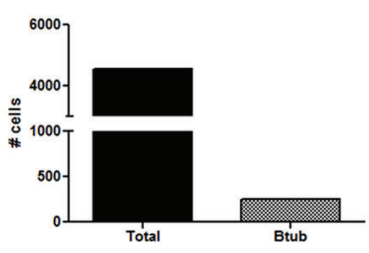

Fig.4. Antigenic expression of differentiated neurospheres from guinea pigs fetuses. (A) After 10 days of cultivation in differentiation conditions, analysis of phenotypic characterization indicated that $13.3 \%$ of analyzed population were positive for marker of undifferentiated neural cells (nestin), (B) about 5.5\% were positive for the marker neurons (beta-III tubulin), (C) about $9 \%$ were positive marker for astrocytes (GFAP) and (D) about 7.8\% were positive for the oligodendrocyte marker. The data correspond to the population analyzed after excluding the dead cell population. 

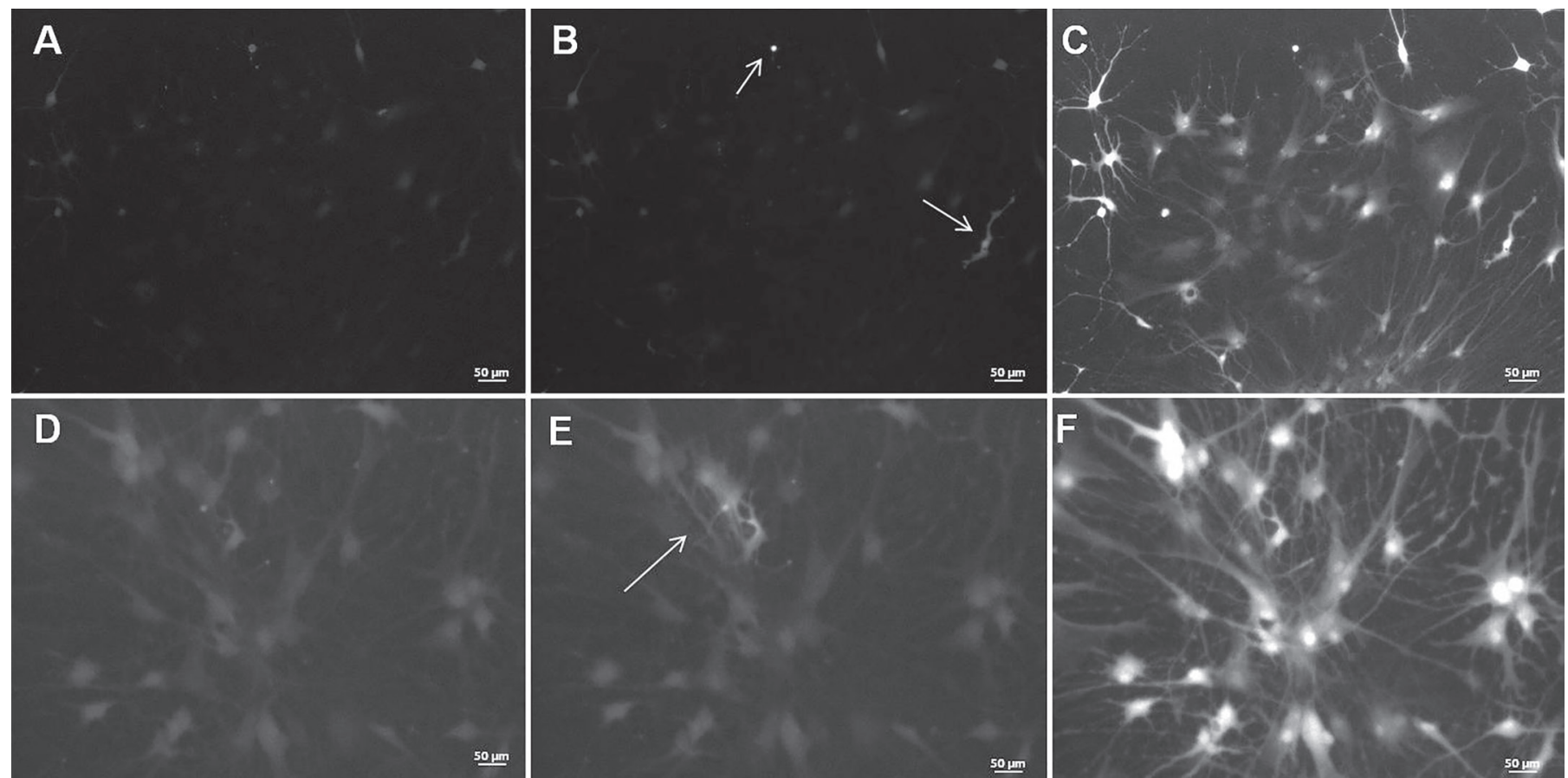

Fig.5. Intracellular $\mathrm{Ca}^{2+}$ influx assay. Cells originated from NSFs cultivated under differentiation conditions for 7 days and then incubated with the $\mathrm{Ca}^{2+}$ intracellular influx marker Fluo 3AM. (A and D) Cells before glutamate and GABA addition to the medium. (B) After glutamate and (E) GABA addition to the medium, some cells were stimulated and $\mathrm{Ca}^{2+}$ influx was detected, showing that NSCs were able to differentiate to excitatory and inhibitory neurons. (C and F) THG addition to the medium stimulates all the cells, characterizing the positive controls. Bar $=50 \mu \mathrm{m}$.

adequate conditions in vitro these cells were able to generate NSFs, which upon dissociation were capable to generate secondary NSFs with similar morphology and proliferation capacity. NSCs derived from the SVZ and cultured as NSFs were cultured over several passages, retaining their proliferative and morphologic properties. Proliferation and differentiation assays demonstrated that cells derived from the NSFs were able to differentiate into the three main cellular populations of the CNS. Staining for nestin, a marker for neural stem cells, and for the three main neural cell types, e.g. neurons (Beta-III-tubulin), astrocytes (GFAP) and oligodendrocytes (mGalC) was observed in NSFs submitted to differentiation. In addition, functional assays after cell differentiation indicated that some NSFs-derived neural cells displayed indicators of neuronal physiology.

We initially identified BrdU-positive cells distributed over the SVZ of newborn guinea pigs. Similar findings were reported by Jiao \& Chen (2008), although Kornack \& Rakic (2001) have identified a discrete and small SVZ area as the exclusive source of neural precursors. Regardless these discrepancies, a fine mapping of BrdU-incorporation may allow for a more precise identification and relative contribution for neurogenesis by different SVZ areas. In our study, the whole SVZ was used as the source of potential NSCs for culture.

Although the protocols and medium composition used for culture, proliferation and differentiation of cells derived from SVZ has been used in mice (Galindo et al. 2011, Filippo et al. 2013), showed to be suitable for guinea pig and, as such, can be thereafter used for this purpose. NSFs were able to proliferate and, upon passages, were capable of ge- nerating new NSFs with similar growth and morphological features of the primary ones. No evidence of cellular senescence was observed in our cultures up to 6-7 passages (4249 days). Svendsen et al. (1997) observed a dramatic decrease in proliferation ability thought successive passages, yet Smith et al. (2003) maintained NSFs cultures up to 140 days and attributed these discrepancies to culture/protocol specificities rather than to biological differences among NSFs from different sources.

NSFs were originally believed to be composed by a homogeneous population of nestin positive cells yet they are currently known to contain a mixed population of true NSCs, precursors and differentiated cells (McLaren et al. 2001, Pastrana et al. 2011). As different SVZ cell populations may originate NSFs and their gene expression changes dynamically through the differentiation process (Pastrana et al. 2011), NSFs may contain cells in distinct differentiation stages and, thus, displaying different markers (McLaren et al. 2001, Martin et al. 2009).

In our study, abundant nestin-positive cells were identified within NSFs and individualized cells as well. Nestin is a marker of immature neural cells and has been detected in SVZ and DG of adult mammals (Doetsch et al. 1997). In previous studies, flow cytometry analises revealed that the rate of nestin-positive cells decreased progressively upon differentiation, from approximately $30 \%$ to $16 \%$ in undifferentiated and differentiated cells, respectively (McLaren et al. 2001, Martin et al. 2009). In the present study we quantified the rate of nestin expression only in cells after differentiation, detecting approximately $13.3 \%$ of cells expressing this marker. 
The expression of Beta-III-tubulin observed after immunostaining in a significant number of NSFs cells after differentiation, indicate that guinea pig SVZ, such as DG may also be a neuron source (Altman \& Das 1967, Palmer et al. 2001, Guidi et al. 2005). Piper et al. (2001) demonstrated that the brain of human fetuses contain neural precursors that generate mature neurons after two weeks in culture. McLaren et al. (2001) concluded that the gradual decrease in nestin-positive cells upon differentiation is due to their replacement by Beta-III-tubulin positive cells that increase from $25 \%$ in undifferentiated cells to $70 \%$ in differentiated cells. In the present study, flow cytometry performed in NSFs-derived cells after 10 days of differentiation revealed approximately 5.5\% Beta-III-tubulin positive cells, a number significantly lower than previous studies. The rate of cells expressing GFAP after differentiation (approximately $9 \%$ of the cells) was also lower than that reported by Ara et al. (2010) and Martin et al. (2009) who reported GFAP staining in $30 \%$ to $35 \%$ of differentiated cells. These differences may indicate that the protocol and/or the stimuli used for differentiation were not as efficient as those used in previous studies.

Upon differentiation under surface-adherent conditions, a number of mGalC-positive cells was observed migrating out of the NSFs. Ren et al. (2009) demonstrated that the composition of the substrate for differentiation may influence NSFs bevavior generating variable proportions of oligodendrocytes. In the present study, a higher number of mGalC positive cells was observed among cells that detached from the NSFs than among cells composing the NSFs. Upon differentiation, approximately $7.8 \%$ of the cells were positive for $\mathrm{mGalC}$ and similar rate (8\%) was observed by Martin et al. (2009). mGalC expression reinforce the multipotentiality of NSFs provenient from the guinea pig SVZ confirming this region as a producer of neural stem cells.

Finally, our study demonstrated that a number of cells derived from NSFs induced to differentiation displayed indicators of neuronal function, as the differentiated cells responded to the neurotransmitters GABA and glutamate. Although the percentage of cells reacting to the neurotransmitters was generally low (approximately $1-2 \%$ ), positive reaction was consistent between trials. Considering that differentiation resulted in a moderate number of differentiated neurons - as demonstrated by flow cytometry - the low number of cells reacting to neurotransmitters should be expected. Piper et al. (2001) characterized neural precursors from human fetal tissue using Fura 2 $\mathrm{AM}$ to measure intracellular $\mathrm{Ca} 2+$. In differentiated cells (14 days) 3-5\% of Beta-III-tubulin positive cells presented reactivity to neurotransmissores GABA ( $4 \% \pm 2 \%)$, glicine $(6 \% \pm 3 \%)$ and glutamate $(12 \% \pm 4 \%)$. This reactivity was not homogeneous in all cell passages indicating that a heterogeneous neuronal population has been generated. The present study did not attempt to correlate neurotransmitter response with cell type yet reaction to GABA and glutamate was restricted to a well defined, restricted population of cells. Addition of THG, in contrast, led to generalized reaction among cultured cells since it releases microsomal stored calcium (Thastrup 1990, Lytton et al. 1991, Bagna- resi et al. 2009). The reactivity to GABA was expected since SVZ-derived neuroblasts migrate rostraly to the olfactory bulbs (OB) where they become mature interneurons (Alvarez-Buylla \& Garcia-Verdugo 2002), and rodent OB interneurons present significant amounts of GABA and dopamine (Kosaka \& Kosaka 2005). The response to glutamate is explained by the fact that it is the predominant excitatory neurotransmitter of the mammal CNS (Cowan et al. 1997).

Taken together these results indicate that a proportion of differentiated cells from the SVZ presented indicators of neuronal functionality, reinforcing that cells from SVZ of guinea pig fetuses present mutipotentiality and may generate functional neural cells in vitro upon adequate culture conditions and stimuli.

Acknowledgements.- The authors are grateful to Claudia Marinovic de Oliveira for giving the samples used in this study, and FAPESP for financial support.

\section{REFERENCES}

Altman J. \& Das G.D. 1967. Postnatal neurogenesis in guinea pig. Nature 214:1098-1101.

Alvarez-Buylla A. \& Garcia-Verdugo J.M. 2002. Neurogenesis in adult subventricular zone. J. Neurosci. 22:629-634.

Alvarez-Buylla A. \& Lois C. 1995. Neuronal stem cells in the brain of adult vertebrates. Stem Cells 13:263-272.

Ara J., Fekete S., Zhu A. \& Frank M. 2010. Characterization of neural stem/ progenitor cells expressing VEGF and its receptors in the subventricular zone of newborn piglet brain. Neurochem. Res. 35:1455-1470.

Bagnaresi P., Alves E., Silva H.B., Epiphanio S., Mota M.M. \& Garcia C.R.S. 2009. Unlike the synchronous Plasmodium falciparum and P.chabaudi infection, the P.berghei and P.yoelii asynchronous infections are not affected by melatonin. Int. J. Gen. Med. 30:47-55.

Buddensiek J., Dressel A., Kowalski M., Runge U., Shroeder H., Hermann A., Kirsch M., Storch A. \& Sabolek M. 2010. Cerebroespinal fluid promotes survival and astroglial differentiation of adult human neural progenitor ell but inhibits proliferation and neuronal differentiation. BMC Neurosci. 11:1471-2202.

Conti L., Reitano E. \& Cattaneo E. 2006. Neural stem cell system: diversities and properties after transplantation animal models of diseases. Brain Pathol. 16:143-154.

Cowan W.M., Jessell T.M. \& Zipursky S.L. 1997. Molecular and Cellular Approaches to Neural Development. Oxford University Press, New York. 563p.

Doetsch F., García-Verdugo J.M. \& Alvarez-Buylla A. 1997. Cellular composition and three-dimensional organization of the subventricular germinal zone in the adult mammalian brain. J. Neurosci. 17:5046-5061.

Filippo T.R.M., Galindo L.T., Barnabe G.F., Ariza C.B., Mello L.E., Juliano M.A., Juliano L. \& Porcionatto M.A. 2013. CXCL12 N-terminal end is sufficient to induce chemotaxis and proliferation of neural stem/progenitor cells. Stem Cell Res. 11:913-925.

Galindo L.T., Filippo T.R.M., Semedo P., Ariza C.B., Moreira C.M., Camara N.O.S. \& Porcionatto M.A. 2011. Mesenchymal stem cell therapy modulates the inflammatory response in experimental traumatic brain injury. Neurol. Res. Int. 1:1-9.

García-Verdugo J.M., Doetsch F., Wichterle H., Lim D.A. \& Alvarez-Buylla A.A. 1998. Architecture and cell types of the adult subventricular zone: in search of the stem cells. J. Neurol. 36:234-248.

Götz M. \& Huttner W.B. 2005. The cell biology of neurogenesis. Mol. Cell Biol. 6:777-788.

Guidi S., Cianti E., Severi S., Contestabile A. \& Bartesaghi R. 2005. Postnatal neurogenesis in the dentate gyrys of the guinea pig. Hippocampus $15: 285-301$ 
Jandial R., Singec I., Duenas V.J., Ho A.L., Levy M.L. \& Snyder E.Y. 2007. Central nervous system repair and stem cells. International Congress Series 1302:154-163.

Jiao J. \& Chen D.F. 2008. Induction of neurogenesis in nonconvetional neurogenic regions of the adult central nervous system by niche astrocyte-produced signals. Stem Cells 26:1221-1230.

Kornack D.R. \& Rakic P. 2001. The generation, migration, and differentiation of olfactory neurons in the adult primate brain. PNAS 98:4752-4757.

Kosaka K. \& Kosaka T. 2005. Synaptic organization of the glomerulus in the main olfactory bulb: compartments of the glomerulus and heterogeneity of the periglomerular cells. Anat. Sci. Int. 80:80-90.

Lacbawan F.L. \& Muenke M. 2002. Central nervous system embryogenesis and its failures. Pediatr. Devel. Pathol. 5:425-447.

Lytton J., Westlin M. \& Hanley M.R. 1991. Thapsigargin inhibits the sarcoplasmatic or endoplasmatic reticulum Ca-ATPase family of calcium pumps. J. Biol. Chem. 266:17067-17071.

Manganas L.N. \& Maletic-Savatic M. 2005. Stem cell therapy for central nervous system demyelinating disease. Curr. Neurol. Neurosci. Rep. 5:225-231.

Mansergh F.C., Wride M.A. \& Rancourt D.E. 2004. Neurons, stem cells and potential therapies, p.177-189. In: Sell S. (Ed.), Stem Cells Handbook. Human Press, New Jersey. 526p.

Martin I., Andres A.R., Védrine S., Tabagh R., Michelle C., Jourdan M-L., Heuze-Vourc'h N., Corcia P., Duittoz A. \& Vourc'h P. 2009. Effect of the oligodendrocyte myelin glycoprotein (OMgp) on the expansion and neuronal differentiation of rat neural stem cells. Brain Res. 1284:22-30.

McLaren F.H., Svendsen C.N., Van der Meide P. \& Joly E. 2001. Analysis of neural stem cells by flow cytometry: Cellular differentiation modifies patterns of MHC expression. J. Neuroimmunol. 112:35-46.
Okano H. 2010. Neural stem cells and strategies for the regeneration of the central nervous system. Proc. Jpn. Acad. 86:438-450.

Palmer T.D., Schwartz P.H., Taupin P., Kaspar B., Stein S.A. \& Gage F.H. 2001. Cell culture: Progenitor cells from human brain after death. Nature 411:42-43.

Pastrana E., Silva-Vargas V. \& Doetsch F. 2011. Eyes wide open: a critical review of sphere-formation as an assay for stem cells. Cell Stem Cell 8:486-498.

Piper D.R., Mujtaba T., Keyong H., Roy N.S., Goldman S.A., Rao M.S. \& Lucero M.T. 2001. Identification and characterization of neuronal precursors and their progeny from human fetal tissue. J. Neurosci. Res. 66:356-368.

Potter G.E. \& Brueck W.L. 1958. Nervous system of guinea pig (Cavia porcellus). Biosci. 19:185-196.

Ren Y-J., Zhang H., Huang H., Wang X-M., Zhou Z-Y., Cui F-Z. \& An Y-H. 2009. In vitro behavior of neural stem cells in response to different chemical functional groups. Biomaterials 30:1036-1044.

Schwartz P.H., Bryant P.J., Fuja T.J., Su H., O'dowd D.K. \& Klassen H. 2003. Isolation and characterization of neural progenitor cells from post-mortem human cortex. J. Neurosci. Res. 74:838-851.

Smith R., Bagga V. \& Fricker-Gates R.A. 2003. Embryonic neural progenitor cells: the effects of species, region, and culture conditions on longterm proliferation and neuronal differentiation. J. Hematoth. Stem Cell 12:713-725.

Svendsen C.N., Skepper J., Rosser A.E., Ter Borg M.G., Tyres P. \& Ryken T. 1997. Restricted growth potential of rat neural precursors as compared to mouse. Brain Res. Dev. Brain Res. 99:253-258.

Thastrup 0. 1990. Role of $\mathrm{Ca}^{2+}$-ATPases in regulation of cellular $\mathrm{Ca}^{2+}$ signaling, as studied with the selective microsomal $\mathrm{Ca}^{2+}$-ATPase inhibitor, thapsigargin. Agents Actions 29:8-15. 